\title{
ESTABILIZAÇÃO DE SOLO COM ADIÇÃO DE LODO DE ESGOTO CALCINADO APLICADO À PAVIMENTAÇÃO
}

\author{
M. Prate' ${ }^{1}$ L. Furlan'; E. Damin ${ }^{3}$ \\ 1,2 Acadêmicas do curso de Engenharia Civil, UDC, Foz do Iguaçu/PR \\ ${ }^{3}$ Engenheiro Civil, especialista, docente do Curso de Engenharia Civil, UDC, Foz do Iguaçu/PR \\ larissa.furlan@hotmail.com¹,makelyps@hotmail.com², eduardodamin@hotmail.com ${ }^{3}$
}

Resumo: A implantação de projeto de esgotamento no país trouxe uma grande contribuição, porém um novo problema: os resíduos gerados ao final do tratamento de esgoto. O lodo de esgoto atualmente tem como destino principal os aterros sanitários e a agricultura. Com o intuito de encontrar uma destinação adequada para este resíduo, o foco deste estudo será submeter o lodo de esgoto, após ativação térmica, a ensaios laboratoriais a fim de encontrar resultados que viabilizem sua utilização como aditivo para estabilização de solos para uso em pavimentos, tendo como finalidade melhorar as características físicas e o desempenho mecânico do solo da Região Oeste do Paraná.

Palavras-chave: Lodo de esgoto calcinado, Pavimento, Estabilização de solo.

\section{Introduçáo}

Segundo [1], o pavimento é composto por várias camadas, que geralmente são constituídas por materiais pétreos, solos, ou a misturas de ambos, e devem trabalhar deformaçóes compatíveis com sua capacidade e natureza. De acordo com [4], quando não é possível a execução das camadas com materiais pétreos, pode-se utilizar o solo. Quando o solo não atende às especificações necessárias, utilizam-se técnicas que melhoram seu desempenho, como a estabilização do mesmo. A estabilização de um solo consiste em melhorar as suas propriedades [3]. Almejando vantagens econômicas e ambientais, busca-se reutilizar e reciclar materiais, tentando proporcionar uma designação adequada para os mesmos. O lodo de esgoto, por exemplo, é considerado o principal subproduto gerado no processo de tratamento de águas residuais, onde a eliminação da matéria orgânica acontece após a caleação e calcinação [2]. Assim, a intenção deste estudo é verificar a viabilidade de estabilizar o solo com a adição do lodo de esgoto calcinado, aplicado para pavimentação.

\section{Metodologia}

O trabalho pretende analisar o comportamento mecânico do Latossolo Vermelho Distroférrico com a adiçáo do lodo de esgoto calcinado, proveniente da estação de tratamento Ouro Verde, da cidade de Foz do Iguaçu, através do ensaio de compactação, compressão simples e CBR (Índice de Suporte Califórnia). 


\section{Resultados esperados/Conclusóes}

Almeja-se alcançar resultados em que a adição de lodo de esgoto, após a calcinação, possa servir para uso de estabilização do solo para aplicação de pavimentação.

\section{Referências}

[1] BALBO, J. T. Pavimentaçáo asfáltica: materiais, projeto e restauração. São Paulo: Oficina de Textos, 2007. 558 p.

[2] CANCELIER, C. D. et al. Estudo da Resistência Mecânica do Solo Condicionado pelo Lodo de Esgoto

Calcinado. 2014. Disponível em: <http://www.abms.com.br/links/bibliotecavirtual/cobramseg >. Acesso em: 10 set. 2016

[3] FRANÇA, F. C. Estabilizaçáo Química de um Solo para Fins Rodoviários: Estudo de Caso Com Produto "Rbi Grade 81". 2003. 129 f. Tese (Doutorado) - Curso de Engenharia Civil, Universidade Federal de Viçosa, Viçosa, 2003.

[4] VILLIBOR, D. F; et al. Pavimentos de baixo custo para vias urbanas: Bases alternativas com solos lateríticos, Gestão de manutenção de vias urbanas. 2. ed. São Paulo: Arte \& Ciência, 2009. 196 p. Disponível em: <www. portaldetecnologia.com.br>. Acesso em: 9 abr. 2017. 